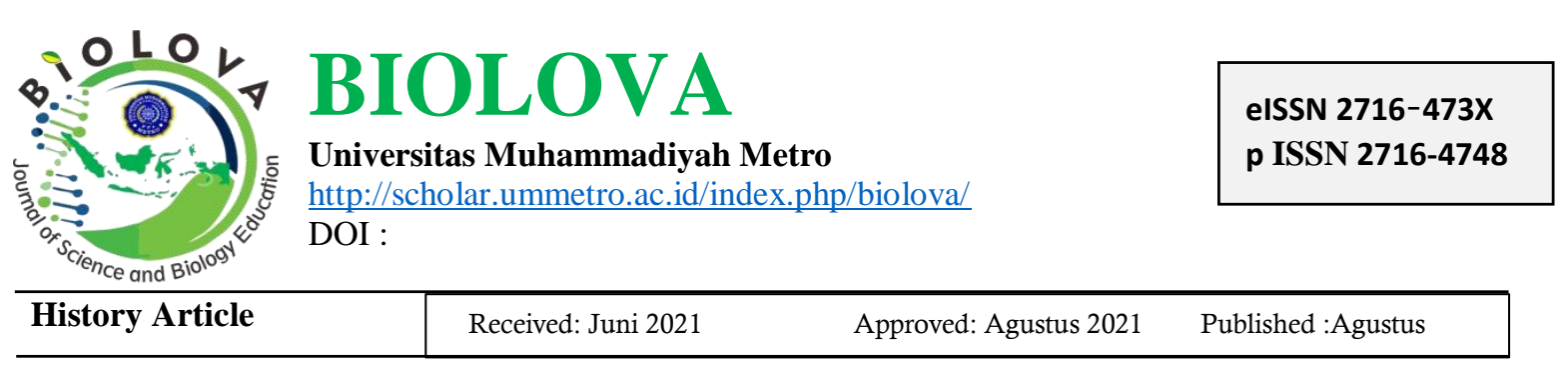

\title{
IDENTIFIKASI BAKTERI PEREDUKSI SULFAT PADA KAWAH AIR PANAS NIRWANA SUOH LAMPUNG BARAT
}

\author{
Agus Sutanto ${ }^{1}$ Mia Cholvistaria ${ }^{2}$ Beny Saputra ${ }^{3}$ Nala Rahmawati ${ }^{4}$ Suprayitno ${ }^{5}$ \\ Program Studi Pendidikan Biologi, Pascasarjana Universitas Muhammadiyah Metro1,2,3,4 \\ SMP Negeri 2 Buana Pemaca Sumantra Selatan5 \\ e-mail: agussutanto11@gmail.com¹, miacholvis89@gmail.com, ${ }^{2}$ benysaputra@ummetro.ac.id ${ }^{3 *}$ \\ nalarahmawati123@gmail.com4 suprayitno0679@gmail.com ${ }^{5}$
}

\begin{abstract}
Abstrak: Bakteri pereduksi sulfat atau Sulfate-reducing bacteria (SRB) adalah jenis bakteri obligat anaerob kemolitrotof memanfaatkan donor electron H2. Kemampuan SRB mereduksi sulfat menjadi sulfida mampu mengendapkan logam toksik meliputi $\mathrm{Cd}, \mathrm{Cu}$, dan $\mathrm{Zn}$ sebagai logam sulfida. SRB memerlukan substrat organik seperti asam piruvat yang dihasilkan oleh aktivitas anaerob lainnya. Mekanisme SRB dalam melakukan reduksi sulfat, sulfat digunakan sebagai sumber energi sebagai akseptor elektron dan menggunakan sumber karbon (C) sebagai donor elekton dalam metabolisme dan bahan penyusun sel. Pada kondisi anaerob bahan organik akan berperan sebagai donor elektron. Pembentukan senyawa sulfida melalui proses reduksi yang ditandai oleh penambahan elektron dari bahan organik yang menyebabkan turunnya konsentrasi sulfat dan naiknya $\mathrm{pH}$ lingkungan. SRB pada kawah air panas nirwana ini hidup secara anaerob pada suhu lingkungan 600C - 1000C dengan $\mathrm{pH}$ 7,4 tingkat kekeruhan air cukup keruh dan kandungan air yang mengandung blerang dengan indikator bau seperti telur busuk dan lingkungan sekitar terdiri dari sedimen batu kapur.
\end{abstract}

Kata kunci: Bakteri Pereduksi Sulfat, Kawah Nirwana, Indentifikasi

\begin{abstract}
Sulfate-reducing bacteria (SRB) is a type of chemolithotroph obligate anaerobic bacteria that utilize $\mathrm{H} 2$ electron donors. The ability of SRB to reduce sulfate to sulfide is able to precipitate toxic metals including $\mathrm{Cd}, \mathrm{Cu}$, and $\mathrm{Zn}$ as metal sulfides. SRB requires organic substrates such as pyruvic acid which is produced by other anaerobic activities. The SRB mechanism in reducing sulfate, sulfate is used as an energy source as an electron acceptor and uses a carbon source $(C)$ as an electron donor in metabolism and cell building material. Under anaerobic conditions, organic matter will act as an electron donor. The formation of sulfide compounds through a reduction process is characterized by the addition of electrons from organic matter which causes a decrease in sulfate concentration and an increase in environmental pH. SRB in this nirvana hot spring crater lives anaerobically at an environmental temperature of $600 \mathrm{C}$ $1000 \mathrm{C}$ with a pH of 7.4 the level of turbidity of the water is quite cloudy and the water content contains sulfur with an indicator of smell like rotten eggs and the surrounding environment consists of limestone sediments.
\end{abstract}

Keywords: Sulfate reducing bacteria, Identification, Kawah Nirwana

How to Cite

Sutanto, Agus, Mia Cholvistaria, Beny Saputra, Nala Rahmawati, Suprayitno. 2021. Identifikasi Bakteri Pereduksi Sulfat pada Kawah Air Panas Nirwana Suoh Lampung Barat. Biolova 2(2). 122 - 127. 
Bakteri pereduksi sulfat (SRB) merupakan sekelompok mikroorganisme prokariotik yang tersebar luas di lingkungan anoksik (dasar laut, dasar sungai dan dasar danau, lumpur, saluran usus manusia dan hewan, serta pada permukaan logam (Kushkevych, et.al, 2021) SRB menggunakan sulfat atau hidrogen sebagai akseptor elektron untuk mereduksi sulfat menjadi sulfida.

Sejumlah besar bakteri pereduksi sulfat (SRB), termasuk Desulfovibrio, Desulfainum, Desulfobacca,

Desulfobulbus, Desulfococcus, Desulfonema, Desulfosarcina, Desulfobacter, Desulfobacula, Desulfofaba, Desulfotigumof, Desulfatibacillum, Desulfatitaleof, Desulfatitalea, terdeteksi dan memainkan beberapa peran penting dalam siklus karbon dan sulfur (Zhou et al, 2021). SRB terbagi ke dalam 2 genus, yaitu Desulfotomaculum dan Desulfovibrio. Genus Desulfovibrio mampu hidup pada kisaran $\mathrm{pH} 6$ hingga netral, sedangkan Desulfotomaculum merupakan kelompok SRB yang menyukai suhu yang tinggi (termofil) (Alexander 1977 dalam Widyati, 2007).

Dalam melakukan proses reduksi sulfat, SRB membutuhkan sumber energi yang diperoleh dari sulfat sebagai akseptor elektron dan bahan organik sebagai sumber karbon. yang memiliki peran sebagai donor elekton dalam metabolisme serta bahan penyusun sel. Pada kondisi anaerob, bahan organik akan berperan sebagai donor elektron (Widyati, 2007). Prokariota pereduksi sulfat secara filogenetik dan fisiologis adalah kelompok mikroorganisme yang menggunakan sulfat sebagai akseptor elektron. SRB telah lama dikenal sebagai kunci utama dari siklus karbon dan belerang (Orellana, et.al, 2021).
Pembentukan sulfida dari proses reduksi terjadi ketika sulfat menerima elektron dari bahan organik. Penurunan konsentrasi sulfat mengakibatkan terjadinya peningkatan $\mathrm{pH}$ di dalam tanah. Hal ini terjadi karena proses penggenangan bahan-bahan organik, penggenangan, dan aktivitas SRB yang saling berkaitan. (Widyati, 2007).

Beberapa senyawa sulfur lain seperti thiosulfat, sulfur dan sulfit, dapat direduksi menjadi sulfida atau dapat merubah nitrat menjadi amonium.

Bakteri pereduksi sulfat mampu mendegradasi aseton dan keton yang menggunakan beberapa enzim yaitu tiamin difosfat, mutase dan dehidrogenase spesifik pada spesies Desulfotomaculum arcticum dan Desulfotomaculum geothermicum (Frey,et.al., 2021). SRB tidak memiliki kemampuan hidrolisis polimer polisakarida karena tidak dapat mensitesis enzim. Pengondisian pada bioreaktor anaerob memungkinkan SRB mereduksi sulfat dan mengikat logan Mn. Dalam reaktor tersebut aktivitas fermentasi kelompok bakteri anaerob lain mampu menyediakan substrat organik yang bersifat kompleks. Dalam aktivitas respirasi secara anaerob SRB memerlukan asam organik pendek (Purnamaningsih, dkk., 2017)

Tujuandari penulisan artikel ini adalah untuk mengetahui ciri-ciri lingkungan yang memiliki indikator adanya bakteri pereduksi sulfat.

\section{METODE}

Metode yang digunakan dalam artikel ini adalah studi dokumentasi dengan menggali dan menelaah beberapa teori dan artikel yang berhubungan dengan ciri 
lingkungan yang terdapat bakteri pereduksi sulfat didalamnya.

\section{HASIL dan PEMBAHASAN}

Penelitian pada kawah Nirwana Suoh menunjukan karakteristik air yang mengandung sulfat, hal ini terlihat dari warna air yang keruh dan bau yang menyengat, warna air yang keruh dan berbau busuk merupakan indikator adanya gas hidrogen sulfida $\left(\mathrm{H}_{2} \mathrm{~S}\right)$, demikian pernyataan Casey (dalam Taroreh, 2015). Keberadaan sulfat pada kawah Nirwana ini memungkinkan adanya bakteri pereduksi sulfat. Hal ini selaras dengan pernyataan Fahrudin bahwa SRB termasuk ke dalam mikroorganisme anaerob dengan kemamuan mereduksi asam sulfat $\left(\mathrm{H}_{2} \mathrm{SO}_{4}\right)$ menjadi sulfida $\left(\mathrm{H}_{2} \mathrm{~S}\right)$ yang banyak hidup pada lingkungan dengan kandungan oksigen yang minim, termasuk pada sedimen lahan basah (Fahrudin, 2018).

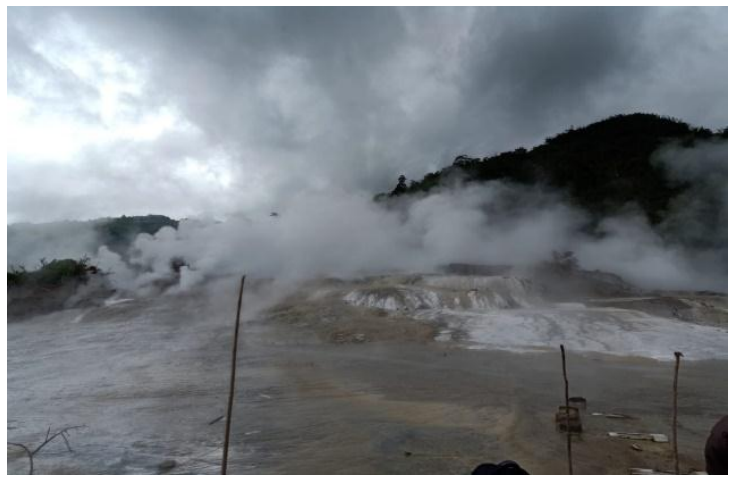

Gambar 1. Kawah Nirwana Suoh (Sumber: dokumentasi pribadi)

Bakteri pereduksi sulfat adalah bakteri yang hidup secara obligat anaerob dengan kemampuan hidup pada lingkungan yang ekstrim. Bakteri ini dapat tumbuh pada suhu berkisar $0^{\circ} \mathrm{C}-100^{\circ} \mathrm{C}$ sedangkan suhu lingkungan pada sumber tepian kawah suhu menunjukan angka $60^{\circ} \mathrm{C}$ dengan $\mathrm{pH}$ berkisar 7,4.

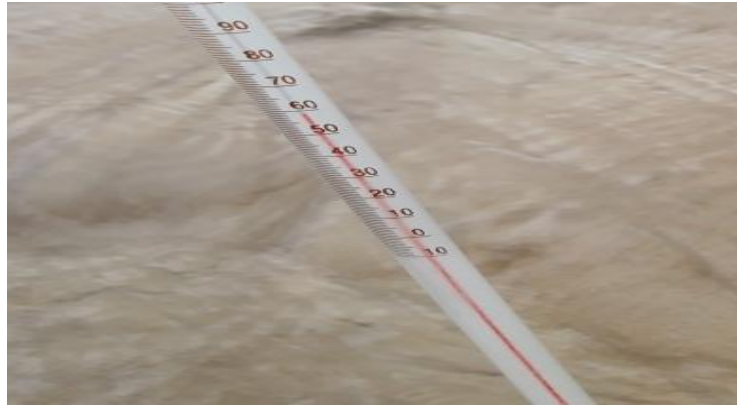

Gambar 2. Hasil pengukuran suhu pada kawah Nirwana. (Sumber: dokumentasi pribadi)

Suhu yang ditunjukkan pada Gambar 2. menunjukan kondisi air yang panas, sekitar $60^{\circ} \mathrm{C}$, hal ini berarti bahwa lingkungan air tersebut terdapat SRB yang hidup pada lingkungan ekstrim dan tergolong ke dalam genus Desulfotomaculum, yakni kelompok SRB yang menyukai suhu yang cenderung (tinggi yang termofil). Bakteri termofilik merupakan bakteri yang mampu bertahan hidup pada kondisi lingkungan yang bersuhu tinggi. Bakteri termofilik adalah salah satu sumber penting enzim termostabil yang dapat diisolasilingkungan panas bumi seperti mata air panas dengan suhu berkisar antara $50-80{ }^{0} \mathrm{C}$ (Runtuboi, dkk., 2018). Sesuai dengan pertumbuhan optimum SRB tercapai pada $\mathrm{pH} 6,6-7,4$ dan suhu $25-40^{\circ} \mathrm{C}$ atau bahkan ada yang mencapai $65-70^{\circ} \mathrm{C}$. Sementara beberapa artikel lain menyebutkan bahwa bakteri pereduksi sulfat dapat hidup bervariasi yaitu pada suhu $0^{\circ} \mathrm{C}$ sampai dengan $100^{\circ} \mathrm{C}$.

$$
\text { Berbagai penelitian telah }
$$
membuktikan kehadiran SRB pada sumber air panas yang mengandung sulfur, diantaranya Suhartanti (2004) menemukan bakteri perduksi sulfat pada air panas Kamojang, Jawa Barat. Di alam, dalam aktivitas bioremediasi lingkungan tanpa oksigen, SRB sering berasosiasi dengan bakteri pereduksi besi (iron reduction 
bacteria). SRB menggunakan akseptor elektron berupa sulfat, sedangkan bakteri pereduksi besi (BPB) menggunakan besi (III) sebagai akseptor elektron terminal (Luef et. al., 2013). Kehadiran SRB di lokasi pemandian air panas Saronsong (Taroreh et. Al., 2015), membuktikan adanya dugaan aktivitas bakteri SRB melalui rangkaian uji reduksi kandungan sulfat sampel air panas, namun penelitian ini belum mengkaji jenis bakteri apakah yang memiliki kemampuan reduksi sulfat tersebut. Hal ini memberikan indikasi kuat tentang keberadaan SRB termofilik di area geothermal Sarongsong.

SRB dalam kondisi anaerob dapat mereduksi sulfat menjadi sulfida, selanjutnya $\mathrm{H}_{2} \mathrm{~S}$ yang telah terbentuk dapat mengendapkan logam-logam toksik seperti $\mathrm{Cu}, \mathrm{Zn}$, dan Cd sebagai logam sulfida. SRB memerlukan asam piruvat yaitu substrat organik yang berasal dari asam organik berantai pendek. Dalam kondisi alamiah, asam piruvat dihasilkan oleh aktivitas anaerob lainnya. Hasil penelitian Posumah dan Rondonuwu (2018) menunjukkan anggota genus Desulfotomaculum mempunyai bentuk sel batang-batang yang pendek, endosora positif, anaerobik, motilitas positif, sumber karbon laktat, gram positif, dan penghasil sulfida,

Karbon selain sebagai donor elekton dalam metabolisme juga berperan sebagai bahan penyusun selnya. Bahan organik akan berperan sebagai donor electron pada kondisi anaerob (Widyati, 2007). Sulfat yang telah menerima elektron dari bahan organik, akan mengalami reduksi dan membentuk senyawa sulfida. Derajat keasaman ( $\mathrm{pH})$ pada tanah akan mengalamai peningkatan seiring dengan menurunnya konsentrasi sulfat. Hal ini terjadi karena keterkaitan beberapa proses yaitu penggenangan, penambahan bahan organik dan aktivitas SRB (Widyati, 2007). Keuntungan memanfaatkan bakteri pereduksi sulfat untuk meningkatkan $\mathrm{pH}$ dan meremediasi logam-logam berbahaya (Sari dkk, 2020).

\section{KESIMPULAN}

Dapat disimpulkan bahwa pada kawah air panas nirwana Suoh Lampung Barat teridentifikasi adanya bakteri pereduksi sulfat berdasarkan identifikasi lingkungan optimum hidup bakteri tersebut.

\section{SARAN}

Disarankan dalam penelitian selanjutnya untuk mengisolasi bakteri pereduksi sulfat sehingga genus atau spesies yang berada pada lingkungan tersebut benar-benar valid.

\section{DAFTAR RUJUKAN}

Fahrudin, dan As'adi Abdulloh. 2018. Analisis Populasi Bakteri pada Air Asam Tambang dengan Perlakuan Sedimen Mangrove. Jurnal Ilmu Alam dan Lingkunga, 9(17): 7077.

Frey, Jasmin, Sophie Kaßner, Bernhard Schink. 2021. Two Marine Desulfotomaculum spp. of Diferent Origin are Capable of Utilizing Acetone and Higher Ketones. Journal Current Microbiology. 78:1763-1770.

Hanafiah A,S,T. Sabrina, H. Guchi. 2009. Ekologi dan Biologi Tanah. USU Press: Medan.

Ismail, M. Yahaya, N. Bakar, A. Noor, M. 2014. Cultivation Of Sulphate Reducing Bacteria In Different Media. Malaysian journal of Civil Engineering 26(3):456-465. 
Kushkevych, Ivan, Dani Dordevi'c, Monika Vít `ezová, Simon K.-M. R. Rittmann. 2021. Environmental Impact of Sulfate-Reducing Bacteria,

Their Role in Intestinal Bowel Diseases, and Possible Control by Bacteriophages. Journal Applied Sciences. 2021, 11, 735. 1-16.

Kushkevych, Ivan, Blanka Hýžová, Monika Vít `ezová, Simon K.-M. R. Rittman. 2021. Microscopic Methods for Identification of Sulfate-Reducing

Bacteria from Various Habitats. International Journal of Molecular Sciences. 2021, 22, 4007. 1-27.

Luef, Birgit., Sirine ,F. Roseann ,C. Kelly ,W. Kenneth ,W. Michael, W. Kenneth, D. Philip, L. Louis, C. Jillian, B. 2012. Iron-Reducing Bacteria Accumulate Ferric Oxyhydroxide Nanoparticle Aggregates that may Support Planktonic Growth. The ISME Journal. 7 html 338-350.

Natsir, Muhammad Halim, Eko Widodo, dan Osfar Sjofjan. 2017. Industri Pakan Ternak. Malang: UB Press.

Orellana, Roberto, Alejandra Arancibia, Leonardo Badilla, Jonathan Acosta, Gabriela Arancibia, Rodrigo Escar, Gustavo Ferrada, Michael Seeger. 2021. Ecophysiological Features Shape the Distribution of Prophages and CRISPR in Sulfate Reducing Prokaryotes. Journal Microorganism. 9. 931. 2021. 123.

Posumah, Dany., Dewianti A.Rondonuwu. 2018. Isolasi dan Identifikasi Bakteri Termofilik Pereduksi Sulfat di Air Panas Sarongsong
Kota Tomohon. Jurnal Biota. Vol. 4 No. 1 Edisi Januari 2018.

Prihatminingsih, Galuh Estu, Purnomoadi, dan Dian Harjanti. 2015. Hubungan antara konsumsi protein dengan produksi, protein dan laktosa susu kambing Peranakan Ettawa. Jurnal IlmuIlmu Peternakan. 25 (2): 20 - 27 ISSN: 0852-3581. Semarang: Fakultas Peternakan dan Pertanian Universitas Diponegoro.

Purnamaningsih, Nur'aini, Endah Retnaningrum, Wahyu Wilopo. 2017. Pemanfataan Konsorsium Bakteri Pereduksi Sulfat dan Zeolit Alam dalam Pengendapan Logam Mn. Jurnal Penelitian Saintek. Vol. 22, Nomor 1, April 2017.

Runtuboi, Dirk Y.P., Tri Gunaedi, Maria Simonapendi, Nadya N.L. Pakpahan. 2018. Isolasi dan Identifikasi Bakteri Termofilik dari Sumber Air Panas di

Moso Distrik Muara Tami Kota Jayapura Provinsi Papua. Jurnal Biologi Papua. Vol 10, No 2, Halaman: 68-73 Oktober 2018.

Sari, Dian Kurnia., Euis Kusniawati, Renta Srimardani. 2020. Peningkatan Kualitas Air Asam Tambang Menggunakan Zeolit dan Bakteri sebagai Media Adsorpsi dengan Metode Sedimentasi secara Anaerob di PT Bukit Asam, tbk. Tanjung Enim, Sumatera Selatan. Jurnal Teknik Patra Akademik. Volume 11 No 1 Bulan Juli 2020.

Suhartanti, D. 2004. Isolasi dan Identifikasi Bakteri Pereduksi Sulfat dari Kawasan PLTP Kamojang Jawa Barat. Prosiding Seminar Nasional. Prodi Biologi FMIPA Universitas Ahmad Dahlan Yogyakarta. 
Sutowo, I, T Adelina, dan D. Febriana. 2016. Kualitas Nutrisi Silase Limbah Pisang (Batang dan Bonggol) dan Level Molases yang Berbeda sebagai Pakan Alternatif Ternak Ruminansia. Jurnal Peternakan. Vol 13 No 2 September 2016 (41 - 47). ISSN 1829 - 8729. Riau: Fakultas Pertanian Dan Peternakan UIN Suska Riau.

Taroreh, F,L. Karwur, F,F. Mangimbulude ,J,C. 2015. Reduksi Sulfat oleh Bakteri Termofilik dari Air Panas Saronsong Kota Tomohon. Prosiding Seminar Nasional Teknik Kimia "Kejuangan" Pengembangan Teknologi Kimia Untuk Pengelolaan Sumber Daya Alam Indonesia. Yogjakarta

Widyati, E. 2007. Pemanfaatan Bakteri Pereduksi Sulfat untuk Bioremediasi Tanah Bekas Tambang Batubara. Jurnal Biodiversitas. Volume 8, Nomor 4, Halaman 283-286.

Zhou, Lijie., Pingxiang Qu, Bikai Zhao, Wenyu Zhang, KeYu, Kang Xie, Wei Qin Zhuang. 2021. Assimilatory and dissimilatory sulfate reduction in the bacterial diversity of biofoulant from a full-scale biofilm-membrane bioreactor for textile wastewater treatment. Journal Elsevier Science of The Total Environment. Volume 772, 10 June 2021, 145464. 